\title{
USUL AL-FIQH: ITS EPISTEMOLOGY, PURPOSE, AND USE
}

\author{
Rasyid Al-Hafizh \\ UIN Imam Bonjol Padang \\ Email: Rasyidalhafizh1996@gmail.com \\ Fachrul Rozy \\ UIN Imam Bonjol Padang \\ Email: Rozyf7032@gmail.com \\ Zaim Rais \\ UIN Imam Bonjol Padang \\ Email: zaimrais@uinib.ac.id
}

\begin{abstract}
The study of Usul Fiqh only feels essential when it deals with different problems whose orders it executes not involve in the offer of the old Fiqh. Besides that, with the rising number of participants of comparative school legislation alike to discover out which idea is more powerful, since closely as the effort to transform Islamic rule, it will increase appeared in how urgent the role of Ushul Fiqh is. The paper tries to present this discussion to suggest the relevance of this idea of Fiqh in dealing with legal issues dealt with by Muslims who sometimes put on nonessential issues. The author organized research with a comparative descriptive analysis. This study organized a view of the works of Usul Fiqh along with the rules contained there in along with the development of Usul Fiqh and its benefits from time to time. The authors identify that Ushul Fiqh plays a highly considerable position in the improvement of Islamic law. Not merely that, Usul Fiqh, the essential function of Usul Fiqh, is to improve someone to find out the rules they take based on syar'i arguments, so that they do not rely very often on considering other people whose bases they do not have. There are not a few obstacles in the Islamic world community with the presence of discoveries by scientists who require answers and confidence of Islamic law.
\end{abstract}

Keywords: Epistemology, Scope, Usul Fiqh.

Abstrak

Studi Ushul Fiqh baru terasa penting bilamana dihadapkan kepada masalah-masalah baru yang hukumnya tidak terdapat dalam perbendaharaan Fiqh lama. Disamping itu, dengan maraknya para peminat hukum perbandingan mazhab, bahkan untuk mengetahui mana pendapat yang lebih kuat, serta adanya upaya untuk memperbarui hukum Islam, akan semakin terasa betapa pentingnya peranan Ushul Fiqh. Tujuan penulis memaparkan pembahasan ini untuk mengingkatkan betapa pentingnya Usul fiqh ini dalam menghadapi permasalahan hukum yang dihadapi oleh umat Islam yang kadangkala telah terfokus kepada permasalahan yang tidak essensial. Penulis melakukan studi Pustaka dengan pendekatan analisis deskriptif komparatif, dilakukan tela'ah terhadap kitab-kitab Ushul Fiqh serta kaidah-kaidah yang ada didalamnya dan perkembangan Ushul Fiqh dan manfaatnya dari masa ke masa. Penulis mendapatkan peranan Ushul Fiqh sangat signifikan dalam pengembangan hukum Islam. Tidak hanya sampai disitu peran utama Ushul Fiqh adalah mendidik seseorang agar memahami hukum yang ia terima berdasarkan dalil syar'i, sehingga ia tidak terlalu menggantungkan diri pada pemahaman orang lain yang tidak ia ketahui dasarnya. Tidak sedikit permasalahan yang timbul di dalam masyarakat dunia Islam dengan hadirnya penemuan-penemuan baru oleh para Ilmuwan yang membutuhkan jawaban dan kepastian hukum Islam.

Kata Kunci: Epistemologi, Ruang Lingkup, Usul Fiqh. 
Rasyid Al-Hafizh, Fachrul Rozy \& Zaim Rais:

Usul Al-Fiqh: Its Epistemology, Purpose, and Use

\section{Introduction}

Al-Quran, as a guide for Muslims in the outline, contains the basics of faith, morals, and sharia or law for the survival of creatures in this universe. The Prophet Muhammad SAW described the contents of the Koran as the interpreter of the Kalamulah throughout his life. When he was alive, someone could immediately know every case that arose as the answer based on the text of the Koran and the explanation and interpretation, which became known as his Sunnah. However, in the next period, people's life experienced a very rapid development along with the development of Islam throughout the world. Contact between Arabs and other nations outside of Arabia with various cultural features has led to new cases that require immediate solutions and alternatives to answer them. ${ }^{1}$

The scientific implication of Usul Fiqh is interesting because it combines two essential elements, revelation and logic. As a scientific discipline with specific procedures and steps, it built Usul Fiqh besides referring to the revelation text; it is also based on the logic of thinking systematically and procedurally. In contrast to scientific disciplines, which generally only refer to one of logic revelation, Ushul Fiqh appreciates both of them as integrated. Besides the basis of revelation as the arguments of the kulli. Usul Fiqh also has a cause for empirical science with some simplification process in it. We deem simplification here necessary because the reality of life as an object of law has a complex character with samples of the various factors involved in it. It is in this context that the science of Usul Fiqh aims to bridge the existence of revelation texts that reveal many problems globally with the social realities of a society that continue to move dynamically. ${ }^{2}$

In the history's development of Ushul Fiqh known as the Madrasah Ushul Fiqh or the Stream of Thought Usul Fiqh. The question is, how does the process that preceded the emergence of the Usul Fiqh flow? And what is no less important to note is the development of Usul Fiqh thinking in the period of Imam Madzhab, which also colored the birth of Madrasah Usul Fiqh. There are at least three periods of development of Usul Fiqh that precede the birth of Usul fiqh madrasah. The three periods are: First, the Time Before Imam Syafi'i, Second Time Imam Syafi'i, and Third Time after Imam Syafi'i. The time before the emergence of marked Imam Shafi'i Imam Abu Hanifa bin Nu'man (died $150 \mathrm{H}$ ). they saw him as the founder of the Hanafi sect. He lived and developed his thinking in Iraq. ${ }^{3}$

We cannot separate the growth of the proposal of Fiqh from the development of Islamic law since the time of the Prophet Muhammad. Until the compilation of Usul

\footnotetext{
${ }^{1}$ Meirison, "Legal Drafting in the Ottoman Period."

2 Yazid, "Mendialogkan Dimensi Keilmuan Ushul Fiqh."

${ }^{3}$ Yazid.
}

DIKTUM: Jurnal Syariah dan Hukum Volume 19 Nomor 1 Juli 2021 
Rasyid Al-Hafizh, Fachrul Rozy \& Zaim Rais:

Usul Al-Fiqh: Its Epistemology, Purpose, and Use

Fiqh as one field of science in the 2 nd century Hijri. ${ }^{4}$ At the time of the Prophet Muhammad. There are only two sources of Islamic law, namely the Qur'an and the Sunnah. If a case arises, Rasulullah SAW. He was waiting for the revelation explaining the law of the case. If the revelation did not come down, then he established the case law through his words, which became known as the hadith or Sunnah. ${ }^{5}$

For a long time, to make it easier for science prosecutors to deepen this noble religious knowledge, salaf scholars have outlined proposals or foundations in each scientific discipline. In the science of interpretation, there are suggestions for performance. In the science of hadith, there are also hadith suggestions. ${ }^{6}$ Likewise, in the jurisprudence discipline, we recognize fiqh proposals - the direction of Fiqh, a combination of two words that are familiar to those who claim knowledge. Many of us may know the existence of the idea of Fiqh as a religious discipline. However, few of us have explored this one knowledge. One factor is our lack of understanding of the urgency of this discipline that was born 12 centuries ago. In fact, if we dive deeper, we realize that the science of jurisprudence is fundamental, especially to study and deepen jurisprudence, which in point always intersects with daily practice even further. Therefore, there is nothing wrong with this opportunity; we will try to get to know the science of jurisprudence, its meaning, scope, urgency, and other matters related to it. ${ }^{7}$ I hope that after getting to know him; they moved us to be more enthusiastic about studying it, deepen it in such a way, or even become experts in the field.

\section{Method}

This article uses literature study, so the method used is library research. Researchers only reviewed library data related to Usul Figh issue which is sourced from ready-library data as an object of study (Snyder, 2019). The literature research process conducted by reviewing literature and analyzing relevant topics to research problems. ${ }^{8}$ The library research can take advantage of library resources as journals, books, dictionaries, documents, magazines and other sources conducting no field research. Next, after collecting some research data, then analyzing the data using comparative descriptive qualitative analysis model. Finally, the descriptive analysis

${ }^{4}$ Arqub, Minhaj Syari'ah Fi Tasyri' al-Ahkam Wa Atsaruhu Fi Tawjih al-Ijtihad Fima La Nash Fih.

${ }^{5}$ Akhḍarī, كثناوي، محمد المنتقى, and Coomasie, 77 مختصر الأخضري,

${ }^{6}$ Azhar, Fiqh kontemporer dalam pandangan neomodernisme Islam, 55.

${ }^{7}$ Zuhailīì, al-Wağiz fi 'l-figh al-islāmī, 112.

${ }^{8}$ Mendes, Emilia, et al. "When to update systematic literature reviews in software engineering." Journal of Systems and Software 167 (2020): 110607.

DIKTUM: Jurnal Syariah dan Hukum Volume 19 Nomor 1 Juli 2021 
Rasyid Al-Hafizh, Fachrul Rozy \& Zaim Rais:

Usul Al-Figh: Its Epistemology, Purpose, and Use

results as written sentences got after going through the following stages, namely: collecting, reducing, displaying data, and verification. ${ }^{9}$

\section{Discussion}

\section{Definition of the Proposal of Fiqh}

The proposal of Fiqh in terms of Arabic is tarkib idahfah. Namely, the equivalent of the words Usul and Fiqh. In Arabic, the word proposal is Jama (plural) ('from the word Ashal which means the foundation for building something. Figh means a deep understanding that requires movement of the potential of reason or knowledge that explains Syariah law, which deals with all human actions, whether as words or deeds, taken from existing texts, or Inference Islamic law. Meanwhile, when viewed in terms of terms, there are various opinions of scholars, including: ${ }^{10}$

a. According to Sheikh Abdul Wahab Khalaf in the book Al-Ilm Usul Al-Fiqh, "the proposal of Fiqh is knowledge of the rules and their discussion which is used to establish Islamic laws" relating to human actions from detailed arguments. According to Asy-Syaukani in the book Irsyadul Fuhul ila Tahqiqil Haq min Ilmil Ushul said, "Ushul Figh is a science to know the rules, which can issue sharia law as branch law (furuk') from its clear propositions.

b. Prof Muhammad Abu Zahrah in his book entitled, Usul Fiqih. It defines Usul Figh as rules that explain how (method) of taking (excavation) laws related to human actions from legal evidence.

\section{An object of the Discussion of Ushul Fiqh Science}

Based on the various definitions above, the main items in the Proposal's discussion of Fiqh are: ${ }^{11}$

a. The source of the law and all the details.

b. The method of exploiting legal sources or methods of extracting the law from the source.

c. Requirements for an allowed person to perform istinbath with all his problems. Meanwhile, Muhammad Al-Juhaili detailed the objectives of the study of Usul Fiqh as follows: ${ }^{12}$

a. Sources of the Islamic law that are agreed upon, such as the Qur'an and Sunnah, as well as those that are disputed, such as istihsan and maslahah mursalah.

\footnotetext{
${ }^{9}$ Huberman, Michael, and Matthew B. Miles. The qualitative researcher's companion. Sage, 2002.

${ }^{10}$ Hallāf, 'Ilm ușūl al-figh, 99.

${ }^{11}$ Abdul Karim Zaidan, al-Wajiz fi Ushul al-Fiqh, 21.

${ }^{12}$ Abdul Karim Zaidan, 53.
}

DIKTUM: Jurnal Syariah dan Hukum Volume 19 Nomor 1 
Rasyid Al-Hafizh, Fachrul Rozy \& Zaim Rais:

Usul Al-Fiqh: Its Epistemology, Purpose, and Use

b. Discussion on ijtihad, that is, the conditions and characteristics of people who perform ijtihad.

c. Finding a way out of two outwardly contradictory propositions, verse by verse or Sunnah by Sunnah, etc. both by way of commemoration (Al-Jam'u'wa Attaufiq). Strengthen one (tarjih), abortion one or both conflicting propositions (nasakh / tatsaqut Ad-dalilain).

d. Discussion of sharia 'law which includes conditions and the like, whether in the form of demands, prohibitions, choices, or relief (rukhsah). Also discussed the law, judges, mahkum alaih (people in danger), and others.

e. Discussion of the rules used in determining the law and how to use it.

\section{History of the Emergence of Fiqh Proposition}

They have not separated the growth of Usul Fiqh from the development of Islamic law since the time of Rasulullah SAW. Until the drafting of Fiqh proposal as the field of science in the 2nd century A.H. In the time of Rasulullah SAW., there are only two sources of Islamic law, namely the Qur'an and the Sunnah. When a case arises, Rasulullah SAW - waiting for the revelation to come down, which explains the law of the case. When the revelation does not come down, then he sets the direction of the case through his words, which is then known as hadith or Sunnah. To establish the law of various instances in the time of the Prophet SAW. Which has no provisions in the Qur'an, the scholars of Usul Fiqh concluded that there is a signal that the Prophet SAW? He Determining it through ijtihad. We can know this through the words of the Prophet SAW.:

Meaning: "Indeed I am a (normal) human being, when I command you something related to your religion, then take him. And when I command you something that comes from my opinion, then indeed I am a (normal) human being". (H.R. Muslim from Rafi' ibn Khudaij). ${ }^{13}$ The result of the ijtihad of the Prophet SAW. This automatically becomes the Sunnah as a source of law and evidence for Muslims. ${ }^{14}$

In some cases, the Prophet SAW. It also uses Qiyas when answering the questions of the companions. For example, he Qiyas when answering the question of 'Umar ibn al-Khattab about the invalidation of the fast of someone who kissed his wife. Rasulullah SAW. He then said:

Meaning: "When you gargle in a state of fasting, is your fast void?" 'Umar replied, 'It's okay' (not void). Rasulullah SAW. Then he said, "Then continue

${ }^{13}$ Muslim ibn al-Hajjāj al-Qushayrī et al., Șahīh Muslim, 22/2.

${ }^{14}$ Arqub, Minhaj Syari'ah Fi Tasyri' al-Ahkam Wa Atsaruhu Fi Tawjih al-Ijtihad Fima La Nash Fih.

DIKTUM: Jurnal Syariah dan Hukum Volume 19 Nomor 1 Juli 2021 
Rasyid Al-Hafizh, Fachrul Rozy \& Zaim Rais:

Usul Al-Figh: Its Epistemology, Purpose, and Use

your fast." (H.R. al-Bukhari, Muslim, and Abu Daud). ${ }^{15}$ Rasulullah SAW. In this hadith, by the Usul Fiqh, measured the law of kissing the wife in a state of fasting. If gargling does not invalidate the fast, then kissing the wife does not invalidate the fast. ${ }^{16}$

The ways of the Prophet SAW. In establishing this law, the seed of the emergence of the science of Fiqh is equivalent to "Figh," that is since the Prophet SAW. ${ }^{17}$ This seed is increasingly clear in the time of the Companions, because the revelation and Sunnah of the Prophet no longer exist, while the problems they face are growing. Famous mujtahid figures in the time of the Companions, among them 'Umar bin al-Khattab, 'Ali bin Abi Talib, and 'Abdullah bin Mas'ud. In ijtihad, 'Umar bin al-Khattab often considered the welfare of the ummah, rather than merely applying the Texts of the Islamic ruling outwardly, while it did not achieve the purpose of the law. ${ }^{18}$ For example, for the benefit of the people who were conquered by Islamic forces in an area, 'Umar bin al-Khattab stipulated that Islamic troops did not take the land in that area, but allowed to be worked by the locals, provided that each harvest should be hand over to the Islamic government. Umar bin al-Khattab based on the thought that if the Islamic government took the agricultural land in the area, took this attitude then the people in the area did not have a livelihood, which could consequently burden the State. The scholars of Fiqh argue that the basis of the thought of 'Umar bin al-Khattab, in this case, is for the sake of welfare and benefit (mashlahah). ${ }^{19}$

'Ali ibn Abi Talib also performed ijtihad by using Qiyas, which is qiyas the punishment of the person who drinks alcohol with the sentence of the person who commits qadzaf (accusing lady of committing adultery). The reason for 'Ali ibn Abi Talib is that a person who gets drunk from drinking intoxicants will be delusional. If he is delirious, then his speech can not controll, and will accuse others of adultery. The punishment for the perpetrator is 80 times the punishment. Therefore, the discipline of people who drink alcohol is the same as the punishment for accusing others of committing adultery. The development of problems in the time of the Companions required the expansion of ijtihad efforts. Besides the scattering of the companions in different areas of different cultures, in the same case, the law in one

${ }^{15}$ Abū Dā'ūd Sulaymān ibn al-Ash'ath al-Sijistān̄ì and Sa'īdī, Sunan Abū Dā' $\bar{u} d, 221 / 3$.

${ }^{16}$ Syarifuddin, Garis-garis besar ushul figh, 49.

${ }^{17}$ Abū Zahrah, Ushul figh, 91.

${ }^{18}$ Arqub, Minhaj Syari'ah Fi Tasyri' al-Ahkam Wa Atsaruhu Fi Tawjih al-Ijtihad Fima La Nash Fih.

${ }^{19}$ AbdelHay, Usul al Figh Rise, Developments, Methodologies \& Literature, 43.

DIKTUM: Jurnal Syariah dan Hukum Volume 19 Nomor 1 Juli 2021 
Rasyid Al-Hafizh, Fachrul Rozy \& Zaim Rais:

Usul Al-Figh: Its Epistemology, Purpose, and Use

area may differ from in another. These legal differences stem from differences in views in determining the law in such cases. ${ }^{20}$

In the tabi'in's time (Sahaba followers), the problems of law that emerged became more complex. The tabi'in performed ijtihad in various Islamic areas. In Madinah appeared various fatwas were related to multiple new issues, as stated by Sa'id ibn al-Musayyab. In Iraq appeared 'Alqamah ibn Waqqas, al-Laits, and Ibrahim al-Nakha'i. In Basrah also occurred mujtahids among the tabi'in, such as Hasan alBashri.

The starting points of these Ulama in establishing laws can differ; one looks from mashlahat, while the other shows the direction through Qiyas. Iraqi Ulama Usul Fiqh is better known as the use of ra'yu; in every case they encounter, they try to find various illats; so that with this illat (reasoning of law), they can equate the case law faced with the law with the text. ${ }^{21}$ The attitude of the Iraqi scholars does not mean leaving the Sunnah of Rasulullah SAW., but they take that attitude because there are very few Sunnahs of Rasulullah SAW. that they can find. The scholars of Medina used many the hadiths of the Prophet Muhammad because they could easily trace the Sunnah of the Prophet Muhammad in the area. ${ }^{22}$

This is where the differences begin in deduce jurisprudential law among scholars of Fiqh. As a result, three scholars emerged, namely Madrasah Al-'Irak, Madrasah al-Kufah, and Madrasah al-Madinah. This naming shows the different methods and methods used in exploring the law. In subsequent developments, Madrasah al-'Iraq and Madrasah al-Kufah were better known as Madrasah al-Ra'yi, while Madrasah al-Madinah was known as Madrasah al-Hadith. ${ }^{23}$

a. After that came the mujtahid priests, especially the four school priests, namely: Nu' man ibn al-Tsabit, better known as Imam Abu Hanifah (80-150 H / 699-767 $\mathrm{AD})$,

b. Malik ibn Anas, better known as Imam Malik (93-179 H / 712-795 AD),

c. Muhammad ibn Idris al-Syafi'i, who is more popularly known as Imam alSyafi'i (150-204 H / 767-820 AD),

d. Imam Ahmad ibn Hanbal (164-241 H / 780-855 AD).

Each imam formulates his method of Fiqh proposal so that it is clear the difference between one imam and another imam in dedicating the law from the Qur'an and Sunnah. Imam Abu Hanifah presented a sequence of propositions in committing the law as follows: the Qur'an; Sunnah; fatwa based on the agreement of the companions; fatwas of the tabiin in line with their thoughts; Qiyas (reasoning), and

${ }^{20}$ Meirison, "Implementasi Tanqih Al-Manath Dalam Penerapan Hukum."

${ }^{21}$ Meirison, "The Impact of Foreign Capitulation on Islamic Sharia in the Ottoman Empire."

22 Šiblī Nu 'mānī and Badāyūnī, Sirat-Un-Nabi, 77.

${ }^{23}$ Sali, “Distinction of Justice and Fairness during Umar Bin Abdul Aziz`s Reign.”

DIKTUM: Jurnal Syariah dan Hukum Volume 19 Nomor 1 Juli 2021 
Rasyid Al-Hafizh, Fachrul Rozy \& Zaim Rais:

Usul Al-Fiqh: Its Epistemology, Purpose, and Use

istihsan. Imam Malik, besides adhering to the Qur'an, Sunnah, also made many laws based on the practices of the people of Madinah ('amal Ahl al-Madinah/ the habits of the people of Medina). Imam Malik refuses to practice the Sunnah when there is a contradiction in the Sunnah referred to in the Qur'an. ${ }^{24}$

Furthermore, Imam al-Syafi'i, with his methods of ijtihad and for the first time, recorded the science of Fiqh that is accompanied by his arguments. The book of Fiqh proposal compiled by Imam al-Syafi'i named Al-Risalah. I compiled this book based on the treasures of Fiqh left by the previous companions, tabiin, and Imam mujtahids. Imam Al-Syafi'i tried to study carefully the debate that took place between the scholars of al-hadith based in Medina and the scholars of al-ra'yi in Iraq. From these two streams, Imam al-Syafi'i sought to compromise the views of both streams and formulate his theories of Fiqh. In his book, Al-Risalah, Imam al-Syafi'i tries to show the authentic and non-authentic opinions after conducting various analyzes from the views of both sects, Iraq and Medina. Based on this analysis, he made the theory of Fiqh proposal, which is expected to be the general benchmark in legalizing the law, from one generation to the next. ${ }^{25}$

The content of this book al-Risalah in the time after Imam al-Syafi'i became the material of discussion of the scholars of Usul Fiqh widely. Their argument is as Sharh (explaining) broadly what Imam al-Syafi'i presented in his book, without changing or reducing what is in the book. Some discuss the nature of the analysis and opinion of Imam al-Syafi'i by offering the strengths and weaknesses of Imam al-Syafi'i theory and sometimes express an idea that is contrary to the concept of Imam alSyafi'i. For example, the scholars of Usul Fiqh from among the Hanafi acknowledge the theories of Usul Fiqh Imam al-Syafi'i. Still, they add other methods or approaches, namely istihsan and 'urf in dedicating the law. The scholars of Usul Fiqh Malikiyah also did the same thing. They add ijma 'Ahl al-Madinah (agreement of the people of Madinah) because the status of ijma' Ahl al-Madinah, according to them, is a Sunnah that has been practiced for generations since the time of the Prophet SAW. ${ }^{26}$ Until their time. Imam al-Syafi'i did not accept the ijma 'Ahl al-Madinah as proof of establishing Islamic law. Besides, the scholars of Usul Fiqh Malikiyyah also added the method of istihsan, mashlahah mursalah (both rejected by Imam al -Syafi'i) and the method of sad al-zari'ah. ${ }^{27}$

The Imams of the four Sects agree with the arguments put forward by Imam al-Syafi'i, namely the Qur'an, Sunnah, ijma' and Qiyas. But each sect adds another method of legal intervention, as stated above. In the analysis of contemporary Fiqh

24 Akhḍarī, كثناوي، محمد المنتقى, and Coomasie, 77 مختصر الأخضري.

${ }_{25}$ Yanggo, Pengantar perbandingan mazhab, 55.

26 Akhḍarī, كثناوي، محمد المنتقى, and Coomasie, 79 مختصر الأخضري.

${ }^{27}$ Abdul Karim Zaidan, al-Wajiz fi Ushul al-Figh, 51.

DIKTUM: Jurnal Syariah dan Hukum Volume 19 Nomor 1 Juli 2021 
Rasyid Al-Hafizh, Fachrul Rozy \& Zaim Rais:

Usul Al-Fiqh: Its Epistemology, Purpose, and Use

scholars, such as Husain Hamid Hasan, from the various methods put forward by the Imams of the Sect above, the scholars of Fiqh Syafi'iyyah (followers of Imam al-Syafi'i) accepted the process of 'urf, Maslahah mursalah, and sadd al-zari'ah. However, they reject the way of istihsan and ijma 'Residents of al-Madinah, because it is considered can not be used as one method in Istinbat of Islamic law. Regardless of the differences of opinion among the Fiqh propositions (including among the four Imams of the Sect), about the various methods of ijtihad available. The analysts of the Fiqh Proposals state that in the fourth period of the Imams, the Fiqh propositions found a "perfect" form, so that future generations only choose and use methods that are appropriate to the cases they face in their respective times. ${ }^{28}$

\section{Purpose of Studying Usul Fiqh}

The goal to be achieved from the science of the proposal of Fiqh is to apply detailed rules to the arguments of sharia' to arrive at Islamic laws,' which are 'Amali' showed by those arguments. With the principles of Usul and their discussion, the sharia texts and the regulations contained can be understood. Likewise, it can adequately be understood what the mujtahid ulama planned and how they arrived at this formula. ${ }^{29}$

Indeed, with this method, the scholars have formulated sharia law and have been described in the books of Fiqh. So what else, Usul Fiqh, is for the people who come later? Here, there are two purposes to know that Usul Fiqh. We already know the method of proposing Fiqh planned by previous scholars. Then if one day we face a new problem that cannot be found during the last Fiqh books, we can look for legal answers to this new problem by applying the rules to the results of the previous ulama's formulation. Second, if we face the law of Fiqh, which is described in the books of Fiqh, but experience difficulties in its application because the changes have been so far, and we want to review the old jurisprudence formula or want to plan a law that is by the benefit and demands of the conditions wish to it, then the effort that must be taken is to devise new rules that allow the emergence of unique formulations in Fiqh. Reviewing a law or determining a new law cannot be done if you do not know well the efforts and methods of the old Ulama in formulating the rules. ${ }^{30}$ It will well know this in the science of Usul Fiqh

\section{The Scope of Usul Fiqh and the Difference between Fiqh and Usul Fiqh}

\section{Scope of Usul Fiqh}

${ }^{28}$ Sali, Saharuddin, and Rosdialena, "Takhrij Fikih Dan Permasalahan Kontemporer."

${ }^{29}$ Meirison, "Riba and Justification in Practice in Scholars' Views."

${ }^{30}$ Meirison, "The Impact of Foreign Capitulation on Islamic Sharia in the Ottoman Empire."

DIKTUM: Jurnal Syariah dan Hukum Volume 19 Nomor 1 
Based on the understanding put forward by the jurists, then Dr. Muhammad Wabah Al-Zuhaili said that the object of discussion of jurisprudence that can distinguish from the study of Fiqh is as follows: ${ }^{31}$

1. Syariah propositions used in digging Islamic law, both agreed (such as the argument of the Qur'an and Sunnah), as well as disputed (such as the argument of istihsan and Maslahah Al-mursalah).

2. Find a way out of propositions that are outwardly considered contradictory, either through al-jam'u wa al-taufiq (compromise of offers), date (strengthening of one of the opposing requests), nash or tasaqutal-propositions (second abortion contradictory propositions). For example, the contradiction of verse with verse. Verse with hadith apparently, or paradox of hadith with the opinion of reason.

3. Discussion of ijtihad, conditions, and characteristics of the person who did it (mujtahid), both the general conditions and the special conditions of knowledge that a mujtahid must possess.

4. Discussion on Islamic law, which includes conditions and the like, whether it is a demand to do, a request to abandon an act, a choice between doing or not, or related to the cause of the condition, mani, valid void/facade, Azimah, and rukhsah. In the law, they also discussed the discussion the lawmaker (judge), the person burdened by the law (mahkum' alaihi, the ruling of the law and its conditions, and the deeds that are subject to the law.

5. Discussion of the rules used and how to use them in dedicating the law from the arguments, both through the language limitations of language and the understanding of the purpose. that A nash (verse or hadith) will achieve. Kulli proposition is a general proposition that can include the depth of some instances such as Amar, Nahi, 'Am, Mutlaq, Muqayad, ijma', and Qiyas.

Kulli law is a general law that goes into the depths of several kinds, such as obligatory, haram, legal, and void. It is unwilling to be called kulli (general) law because its depth can include various obligatory acts, such as unwillingness to fulfill promises, obligatory to witness in marriage. Haram is the law of kulli, which provides for several kinds of forbidden actions, such as haram to commit adultery, haram to accuse of committing adultery, haram to steal, haram to kill, etc. ${ }^{32}$

${ }^{31}$ Zuhailī, al-Wağ̀iz fi 'l-figh al-islāmī, 21.

${ }^{32}$ Meirison, "Mashlahah Dan Penerapannya Dalam Siyasah as Syar'iyah.” 
Usul scholars do not discuss the evidence of juz'i (partial), but what they discuss is the proposition and law of kulli, which is placed in the general rules applied by the jurists in each case. On the other hand, the jurists do not discuss the propositions and laws of kulli, but what they discuss is the propositions and laws of juz'i.

\section{Difference between Fiqh and Usul Fiqh}

From the fiqh ta'rif and the above Fiqh proposals, we can conclude that Fiqh is studying and knowing the Islamic religious laws. In contrast, the Fiqh proposals are the rules needed to issue regulations and human actions desired by Fiqih. Usul Fiqh is a measure or provision for legal istinbat, and its object is always a legal argument. In contrast, the item of Fiqh is still mukallaf deeds, which are given legal status. Although there is a point of similarity, namely that they both refer to arguments, their concentration is different, namely Usul fiqh views arguments from the method of designating a provision of law. In contrast, Fiqh views statements only as a reference. Thus, it can be said that the proposition of a tree can bear fruit, while Fiqh is a fruit that is taken from that tree.

Fiqh science is a product of the proposal of Fiqh. Fiqh science developed because of the development of the science of fiqh proposal. The science of Fiqh will be more advanced when the science of Usul Fiqh is progressing because the science of the origin of Fiqh is a kind of science that explains the methods and systems of determining law based on detailed arguments.

The science of jurisprudence is the science of tools that provide various provisions and rules to get a statute of sharia 'law which humans must practice. To make it easier to understand this problem, we present an example of the command to pray based on the Al-Quran and the Hadith of the Prophet Muhammad.

The Word of Allah SWT in the Al-Qur'an chapter Al-Isra verse 78 is:

$$
\text { أقم الصلاة لدلوك الشمش إلى غسق اليل وقرآن الفجرإن قرآن الفجر كان مشهودا }
$$

"Establish prayers from after the sun slips until dark at night and (establish) the dawn prayers; in fact, the dawn prayers are witnessed (by angels)."

The words of the Prophet Muhammad SAW, which reads:

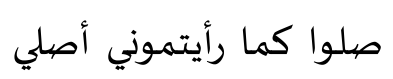


Rasyid Al-Hafizh, Fachrul Rozy \& Zaim Rais:

Usul Al-Fiqh: Its Epistemology, Purpose, and Use

"Pray as you see me praying." (H.R. Muttafaqun alaihi)

From the word of Allah and the hadith of the Prophet above, it is not yet known whether the law is to perform the prayer, obligatory, circumcision, or must. In this matter, Usul fiqh provides the argument that the direction of an order or order is originally compulsory unless other statements turn it away from the original law. We can see this from the sentence of orders or warnings regarding praying for followers of Islam.

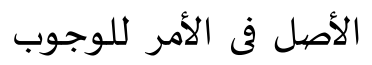

"The point in the order (Amar) shows (that is, the obligatory action ordered)"

\section{Conclusion}

We describe the proposal of Fiqh as a large and fruitful tree. The fruit is ripe to be picked. Then someone came who tried to pick the fruit. This is a simple description of the proposal of Fiqh. The tree is like the source of law in Islam, namely the Koran, sunna, consent, and Qiyas. Simultaneously, the fruit of the tree is the law itself, which is obligatory, sunna, immoral, makruh, or haram. The man who came to pick the fruit was a mujtahid. He wants to reap the fruit of the law from the tree, which is the source of law. Finally, how person picks fruit is a method of issuing the law of a problem from the source of the law itself, which we have mentioned earlier than istidlal or istinbath. Well, the proposal of Fiqh is a discipline that discusses these: trees, fruit, people who pick fruit, and how people pick fruit.

From the epistemological aspect, Usul Fiqh is a scientific theory that focuses on extracting laws based on its arguments. Interestingly, as a legal theory, Usul fiqh combines elements of revelation and logic in an integrated manner in formulating methods and procedures of istinbath al-ahkam. Usul fiqh science is not in space but is present according to the challenges and legal needs. With the dominant logic elements in it, Usul Fiqh is not effortlessly timeless to update every need of society in law.

Proposal of Fiqh has the meaning of al-Usul, which means fiqh arguments, such as the Al-Quran, the Sunnah of the Prophet, Ijmak ', Qiyas, and others. Al-Figh means a deep understanding which requires the direction of the potential of reason. The object of the study of Usul Fiqih, according to Al-Ghazali, discusses shariah law, about the sources of legal arguments, about how to put the law and the sources of that argument and discussions about ijtihad. The scope of Usul Fiqh globally is the source and statement of the law with its various problems, how to use these legal sources and opinions, and others. We can see the history of the development of fiqh proposals in the period of jurisprudence proposals before being recorded and fiqh proposals after being recorded and fiqh proposals after Shafi. The purpose and urgency of Ushul Fiqh are to state the conditions that must be possessed by a mujtahid to explore Islamic

DIKTUM: Jurnal Syariah dan Hukum Volume 19 Nomor 1 Juli 2021 
Rasyid Al-Hafizh, Fachrul Rozy \& Zaim Rais:

Usul Al-Figh: Its Epistemology, Purpose, and Use

Law properly and others. What if the people cannot do it alone? Can it follow a particular opinion or sect? Some circles strongly forbid sectarianism, some even antisectarian. However, some others allow when people cannot dig into Islamic law. Because of the large number of Muslims who cannot do so sectarian in the sense of implementing and practicing the results of ijtihad of mujtahid imams, such as Malik, Syafii, and others, it is obligatory for every Muslim who could not do ijtihad.

DIKTUM: Jurnal Syariah dan Hukum Volume 19 Nomor 1 
Rasyid Al-Hafizh, Fachrul Rozy \& Zaim Rais:

Usul Al-Figh: Its Epistemology, Purpose, and Use

\section{References}

\section{Book}

Abdel Hay, Muhammad Fawzy. Usul al Figh Rise, Developments, Methodologies E Literature. Cairo: Dar al-Salam, 2016.

Abdul Karim Zaidan. al-Wajiz fi Ushul al-Figh. Beirut, Lebanon: Muasasah Risalah, 2011.

Abū Dā'ūd Sulaymān ibn al-Ash'ath al-Sijistānī, and 'Umar Fārūqī Sa 'īdī. Sunan Abū $D \bar{a} ' \bar{u} d$. Lahaur: Dārulislām, 2006.

Abū Zahrah, Muhammad. Ushul figh. Jakarta: Pustaka Firdaus kerjasama dengan Perhimpunan Pengembangan Pesantren dan Masyarakat (P3M), 1999.

Akhḍarī, 'Abd al-Raḥmān ibn Muhammad, كثناوي، محمد المنتقى, and Muntaka Coomasie. Mukhtasar Akhdar fi Mazhab Imam Malik. بيروت: الدار العربية للطباعة والنشر والتوزيع، 1984.

Arqub, Hasan Iwadh Abdu. Minhaj Syari'ah Fi Tasyri' al-Ahkam Wa Atsaruhu Fi Tawjih al-Ijtihad Fima La Nash Fih. International Institute of Islamic Thought, 2017. https://books.google.co.id/books?id=m0MwDwAAQBAJ.

Azhar, Muhammad. Figh kontemporer dalam pandangan neomodernisme Islam. Yogyakarta: Lesiska bekerjasama dengan Pustaka Pelajar, 1996.

Huallāf, 'Abd-al-Wahhāb. 'Ilm uṣūl al-fiqh. al-Qāhira: Dār al-ḥadīt, 2003.

Huberman, Michael, and Matthew B. Miles. The qualitative researcher's companion. Sage, 2002.

Muslim ibn al-Ḥajjāj al-Qushayrī, Abū Țāhir Zubayr 'Alī Za'1̄, Nasiruddin Khattab, Huda Khattab, and Abū Khalīl. Sahị̄h Muslim: English Translation of Sahîh Muslim. 1st ed. Riyadh: Darussalam, 2007.

Šiblī Nu'mānī, and Muhammad Țaiyib Bahš Badāyūn̄i. Sirat-Un-Nabi: The Life of the Prophet Peace Be upon Him. IAD Religio-Philosophy (Reprint) Series. New Delhi: Rightway Publications, 2001.

Syarifuddin, Amir. Garis-garis besar ushul figh. Jakarta: Kencana, 2012.

Yanggo, Huzaemah Tahido. Pengantar perbandingan mazhab. Jakarta: Logos, 1997.

Zuhailī, Wahba az-. al-Wağiz fi 'l-fiqh al-islāmī. Dimašq: Dār al-Fikr, 2005.

DIKTUM: Jurnal Syariah dan Hukum Volume 19 Nomor 1 Juli 2021 
Rasyid Al-Hafizh, Fachrul Rozy \& Zaim Rais:

Usul Al-Fiqh: Its Epistemology, Purpose, and Use

\section{Journal Articles}

Meirison. "The Impact of Foreign Capitulation on Islamic Sharia in the Ottoman Empire." Justicia Islamica Vol.17, no. No.1, June 2020 (2020): 109-26. https://doi.org/10.21154/justicia.

Meirison, Meirison. "Implementasi Tanqih Al-Manath Dalam Penerapan Hukum." Nizham Journal of Islamic Studies; Vol 2 No 1 (2014): Mazhab Hukum Islam Di Indonesia, September 2017. 25, https://ejournal.metrouniv.ac.id/index.php/nizham/article/view/868.

- - - "Legal Drafting in the Ottoman Period." Jurnal Ilmiah Al-Syir'ah 17, no. 1 (June 30, 2019). https://doi.org/10.30984/jis.v17i1.806.

- - - "Mashlahah Dan Penerapannya Dalam Siyasah as Syar'iyah." Ijtihad 32, no. 1 (April 5, 2019). https://doi.org/10.15548/ijt.v32i1.32Sali, Meirison Alizar. "Distinction of Justice and Fairness during Umar Bin Abdul Aziz`s Reign." AJIS: Academic Journal of Islamic Studies 4, no. 2 (December 9, 2019). https://doi.org/10.29240/ajis.v4i2.954.

- - - "Riba and Justification in Practice in Scholars' Views." Transformatif 2, no. 1 (September 20, 2018). https://doi.org/10.23971/tf.v2i1.922.

Mendes, Emilia, et al. "When to update systematic literature reviews in software engineering." Journal of Systems and Software 167 (2020): 110607.

Sali, Meirison Alizar, Desmadi Saharuddin, and Rosdialena Rosdialena. “Takhrij Fikih Dan Permasalahan Kontemporer." Al-Istinbath: Jurnal Hukum Islam 5, no. 1 (May 9, 2020). https://doi.org/10.29240/jhi.v5i1.1235.

Yazid, Abu. "Mendialogkan Dimensi Keilmuan Ushul Fiqh." At-Ta'dib; Vol 7, No 1 (2012): Teori Pendidikan, June 25, 2012. https://ejournal.unida.gontor.ac.id/index.php/tadib/article/view/524.

DIKTUM: Jurnal Syariah dan Hukum Volume 19 Nomor 1 